\title{
Association of Adenovirus 36 Infection With Obesity-Related Gene Variants in Adolescents
}

\author{
L. DUŠÁTKOVÁ ${ }^{1,2}$, H. ZAMRAZILOVÁ ${ }^{1}$, I. ALDHOON HAINEROVÁ ${ }^{1,3}$, \\ R. L. ATKINSON ${ }^{4}$, B. SEDLÁČKOVÁ ${ }^{1,2}$, Z. P. LEE ${ }^{4}$, J. VČELÁK ${ }^{1}$, B. BENDLOVÁ ${ }^{1}$, \\ M. KUNEŠOVÁ ${ }^{1}$, V. HAINER ${ }^{1}$ \\ ${ }^{1}$ Institute of Endocrinology, Prague, Czech Republic, ${ }^{2}$ Faculty of Science, Charles University, \\ Prague, Czech Republic, ${ }^{3}$ Department of Pediatrics and Center for Research of Diabetes, \\ Metabolism and Nutrition, Third Faculty of Medicine, Charles University, Prague, Czech Republic, \\ ${ }^{4}$ Virginia Obesity Research Institute, Richmond, VA, USA
}

Received July 13, 2015

Accepted July 28, 2015

\section{Summary}

Both, common gene variants and human adenovirus 36 (Adv36) are involved in the pathogenesis of obesity. The potential relationship between these two pathogenic factors has not yet been investigated. The aim of our study was to examine the association of obesity susceptibility loci with Adv36 status. Genotyping of ten gene variants (in/near TMEM18, SH2B1, KCTD15, PCSK1, BDNF, SEC16B, MC4R, FTO) and analysis of Adv36 antibodies was performed in 1,027 Czech adolescents aged 13.0-17.9 years. Variants of two genes (PCSK1 and BDNF) were associated with Adv36 seropositivity. A higher prevalence of Adv36 antibody positivity was observed in obesity risk allele carriers of $P C S K 1$ rs6232, rs6235 and BDNF rs4923461 vs. noncarriers $\left(x^{2}=6.59, p=0.010 ; X^{2}=7.56, p=0.023\right.$ and $x^{2}=6.84$, $\mathrm{p}=0.033$, respectively). The increased risk of Adv36 positivity was also found in PCSK1 variants: rs6232 (OR=1.67, $95 \% \mathrm{CI}$ 1.11-2.49, $\mathrm{p}=0.016)$ and rs6235 (OR=1.34, $95 \% \mathrm{CI}$ 1.08-1.67, $\mathrm{p}=0.010)$. PCSK1 rs6232 and BDNF rs925946 variants were closely associated with Adv36 status in boys and girls, respectively $\quad\left(X^{2}=5.09, \quad p=0.024 ; \quad X^{2}=7.29, \quad p=0.026\right)$. Furthermore, PCSK1 rs6235 risk allele was related to Adv36 seropositivity $\left(X^{2}=6.85, p=0.033\right)$ in overweight/obese subgroup. In conclusion, our results suggest that obesity risk variants of PCSK1 and BDNF genes may be related to Adv36 infection.

\section{Key words}

Adolescence - Obesity - Genome-wide association • Single nucleotide polymorphism • Adenovirus 36

\section{Corresponding author}

L. Dusatkova, Obesity Management Center, Institute of Endocrinology, Národní 8, 11694 Prague 1, Czech Republic. Fax: +420224905 325. E-mail: Idusatkova@gmail.com

\section{Introduction}

The prevalence of obesity in children and adolescents remains high despite numerous recent attempts to improve strategies in prevention and treatment (Ahluwalia et al. 2015, Ahrens et al. 2014). Novel insights into the multifactorial pathogenesis of obesity have, however, been made during the last decade. The genome-wide association study (GWAS) approach has identified a number of common variants related to body mass index (BMI) and obesity. Several associations have been replicated in various populations, including in children and adolescents (den Hoed et al. 2010, Nead et al. 2015). A total of 97 gene variants (56 novel) were described by the latest GWAS in 2015 (Locke et al. 2015). Variations have been mostly found in or near unknown genes whose function and impact on body weight regulation still need to be elucidated (Locke et al. 2015). The role of human adenovirus 36 (Adv36) in the pathogenesis of obesity was first documented in experimental animal models (Dhurandhar et al. 2000). Adv36 infection induces adipogenesis by promoting proliferation and differentiation of preadipocytes and by increasing lipid accumulation in adipocytes (Pasarica et al. 2008). An association of Adv36 with increased body 
weight in humans has clearly been confirmed over the last decade (Aldhoon-Hainerova et al. 2014, Atkinson et al. 2005, Shang et al. 2014). An important role of genetic factors in susceptibility to various infectious diseases has been demonstrated by family studies and multiple GWAS (Chapman and Hill 2012). Additionally, an impaired immunity in obesity (Tanaka et al. 1993) leads to a greater susceptibility to different infections (Karlsson et al. 2010). If the pathogenesis of obesity is partly mediated by infectious agents we may speculate whether there is a relationship between obesity susceptibility gene loci and Adv36 infection.

The aim of our study was to investigate the association of ten previously reported gene variants associated with BMI and obesity with Adv36 seropositivity and their relation to gender and body weight in Czech adolescents.

\section{Methods}

\section{Subjects}

A study population consisted of 1,027 Czech adolescents aged 13.0-17.9 years (476 boys and 551 girls; of them 540 were normal weight and 487 overweight/obese) who were selected from the original Childhood Obesity Prevalence and Treatment project (Aldhoon-Hainerova et al. 2014). Only those with complete data on anthropometric parameters, genotypes and Adv36 antibody assessment were included in the present study. All participants and their parent(s) signed an informed consent before the initiation of study procedures. The study protocol was approved by the Ethical Committee of the Institute of Endocrinology in Prague and was in accordance with the Helsinki declaration II.

\section{Anthropometric assessment}

Body height, body weight, BMI and its z-score were assessed as described previously (AldhoonHainerova et al. 2014). Overweight and obesity was defined as BMI $\geq 90^{\text {th }}$ percentile according to the Czech BMI references specified for sex and age (Kobzova et al. 2004).

\section{Genotyping}

Ten single nucleotide polymorphisms (SNPs) rs7561317 (transmembrane protein 18 gene, TMEM18), rs7498665 (SH2B adaptor protein 1 gene, SH2B1), rs29941 (potassium channel tetramerisation domain containing 15 gene, KCTD15), rs6232 and rs6235 (proprotein convertase subtilisin/kexin type 1 gene, PCSK1), rs925946 and rs4923461 (brain-derived neurotrophic factor gene, $B D N F$ ), rs10913469 (SEC16 homolog B S. cerevisiae gene, SEC16B), rs17782313 (melanocortin 4 receptor gene, $M C 4 R$ ) and rs9939609 (fat mass and obesity associated gene, FTO) were studied. SNPs in both the PCSK1 (rs6232, rs6235) and the BDNF (rs925946, rs4923461) were analyzed separately due to their incomplete linkage (Dusatkova et al. 2013). Genotyping was performed using the TaqMan SNP Genotyping Assays (Applied Biosystems, Waltham, MA, USA) on a Biomark (Fluidigm, South San Francisco, CA, USA) and LightCycler 480 (Roche, Basel, Switzerland) and described in detail by Dusatkova et al. (2013). In the present study all SNPs followed the Hardy-Weinberg equilibrium (evaluated by chi-square test, $\mathrm{p}>0.05$ ).

\section{Adv36 antibody assessment}

The detection of Adv36 antibodies from serum was done by a competitive enzyme-linked immunosorbent assay developed by Obetech, LLC (Richmond, VA, USA).

\section{Statistical analyses}

Characteristics of Adv36 negative and Adv36 positive groups were compared using chi-squared test for descriptive variables and nonparametric Mann-Whitney test for quantitative variables (expressed as medians with lower and upper quartiles). Chi-squared tests and odds ratios (ORs) were calculated to determine associations of Adv36 seropositivity with genotypes and alleles, respectively. Analyses with genotypes were performed in the whole cohort as well as in subgroups stratified by gender and body weight. When the number of minor homozygotes was less than five, they were combined with heterozygotes for such a genotype. Statistical software NCSS 2004 (NCSS, LLC, Kaysville, UT, USA) was used. P-value (two-tailed) $<0.05$ was considered statistically significant.

\section{Results}

Of the total 1,027 adolescents, $26.4 \%$ presented with positive Adv36 antibodies. The basic characteristics of the cohort based on Adv36 antibody status are shown in Table 1. A significantly higher prevalence of Adv36 antibody positivity was found in girls as compared to 
boys (Table 1). Genotype distributions and risk allele frequencies according to Adv36 status are presented in Table 2. Obesity risk allele carriers of PCSK1 rs6232, $P C S K 1$ rs6235 and BDNF rs4923461 had significantly higher prevalence of Adv36 positivity than non-carriers (Table 2). Also the other $B D N F$ variant rs $925946 \mathrm{had}$ a borderline association with Adv36 infection (Table 2). Furthermore, both minor alleles of PCSK1 increased chances of having positive Adv36 antibodies (Table 2). Analyses taking into account gender revealed a higher prevalence of Adv36 positivity in males carrying risk PCSK1 rs6232 $\left(\chi^{2}=5.09, \mathrm{p}=0.024\right)$ and in females carrying risk allele $B D N F$ rs925946 $\left(\chi^{2}=7.29, \mathrm{p}=0.026\right)$. When stratified by body weight, the relation of PCSK1 rs6235 with Adv36 was confirmed in the overweight/obese subgroup $\left(\chi^{2}=6.85, \mathrm{p}=0.033\right)$.

Table 1. Characteristics of the study population according to the presence of Adv36 antibodies.

\begin{tabular}{lccc}
\hline Characteristics & Adv36- & Adv36+ & p \\
\hline All (n=1027) & $756(73.6 \%)$ & $271(26.4 \%)$ & \\
Boys/girls & $383 / 373$ & $93 / 178$ & $<0.001^{\mathrm{a}}$ \\
Age (years) & $15.7(14.5 ; 16.8)$ & $15.8(14.7 ; 16.9)$ & $0.445^{\mathrm{b}}$ \\
BMI z-score & $0.5(-0.1 ; 2.6)$ & $1.5(0.1 ; 2.8)$ & $0.027^{\mathrm{b}}$ \\
Overweight & $333(44.1 \%)$ & $154(56.8 \%)$ & $<0.001^{\mathrm{a}}$ \\
Boys (n=476) & $383(80.5 \%)$ & $93(19.5 \%)$ & \\
Age (years) & $15.6(14.4 ; 16.7)$ & $15.9(15.1 ; 16.9)$ & $0.134^{\mathrm{b}}$ \\
BMI z-score & $0.5(0 ; 2.6)$ & $1.3(0.1 ; 2.7)$ & $0.227^{\mathrm{b}}$ \\
Overweight & $171(44.7 \%)$ & $50(53.8 \%)$ & $0.114^{\mathrm{a}}$ \\
Girls (n=551) & $373(67.7 \%)$ & $178(32.3 \%)$ & \\
Age (years) & $15.9(14.8 ; 16.9)$ & $15.7(14.6 ; 17)$ & $0.560^{\mathrm{b}}$ \\
BMI z-score & $0.5(-0.1 ; 2.7)$ & $1.6(0 ; 2.8)$ & $0.082^{\mathrm{b}}$ \\
Overweight & $162(43.4 \%)$ & $104(58.4 \%)$ & $0.001^{\mathrm{a}}$ \\
\hline
\end{tabular}

Quantitative data are described as medians (lower; upper quartiles). a $\mathrm{p}$-values were derived from chi-squared tests, ${ }^{\mathrm{b}}$ from Mann-Whitney tests. Adv36-, adenovirus 36 antibody negative; Adv36+, adenovirus 36 antibody positive; BMI, body mass index.

\section{Discussion}

Our association study of 1,027 Czech adolescents is the first to investigate the relationship between obesity susceptibility loci and Adv36 antibody status. As all identified GWAS loci are able to explain not more than $2.7 \%$ of variation in BMI and their predictive value is low (Locke et al. 2015), an elucidation of these mostly unknown genes in pathophysiology of obesity could be valuable. Of ten examined gene variants, variants of two genes showed some relation to the presence of Adv36 antibodies. The obesity risk alleles rs6232 and rs6235 of PCSK1 and rs4923461 of BDNF were associated with a higher prevalence of Adv36 seropositivity in both genders regardless of body weight. The same tendency was observed for rs925946 of BDNF but only in girls. PCSK1 encodes a protease from the subtilisin-like proprotein convertase family that process polypeptide hormones and neuropeptide precursors (Jansen et al. 1995). The rs6232 variant encodes a substitution N221D that reduces catalytic activity of the protease and leads to obesity, while the rs6235 (S690T) had no effect on catalytic activity (Benzinou et al. 2008). BDNF, a member of the nerve growth factor family essential for survival of striatal neurons in the brain, is involved in hypothalamic regulation of energy balance through the leptinmelanocortin signaling pathway (Nicholson et al. 2007). Both, rs4923461 and rs925946 are intergenic variants localized within the $B D N F$ antisense non-coding transcript. It was shown that inhibition of this transcript upregulates BDNF mRNA (Modarresi et al. 2012), thus we could speculate that examined $B D N F$ variants influence $B D N F$ expression and consequently energy homeostasis. The minor allele of PCSK1 rs6235 was significantly more prevalent in Adv36 positive overweight/obese subgroup, but not in normal weight counterparts. In obese subjects, particularly in those extremely obese, a more severe course of infectious diseases has been shown (Almond et al. 2013, Garcia et al. 2015). An association between obesity risk alleles and Adv36 seropositivity may partly be due to a greater susceptibility of obese individuals to infection. In addition, the combined effect of Adv36 infection with obesity risk genotype in the development of obesity should also be considered. An expression of PCSK1 and BDNF is mainly situated to hypothalamic regions and mutations in these genes cause rare monogenic forms of early onset obesity (Hinney et al. 2014). The adipogenic effect of Adv36 studied in rats was also confirmed in the central nervous system (Pasarica et al. 2006). Moreover, Adv36 reduces leptin production (Vangipuram et al. 2007). Until now we may only speculate if these gene variants influence the susceptibility to Adv36 infection and consequently body weight. Nevertheless, we would point out the important role of genetic susceptibility as well as the role of Adv36 infection in body weight regulation. The major limitation of our study is the size of our cohort, which may not be sufficiently powered to detect low effects of common gene variants. 
Table 2. Associations of ten gene variants with the presence of Adv36 antibodies.

\begin{tabular}{|c|c|c|c|c|c|c|}
\hline \multirow{2}{*}{$\begin{array}{c}\text { Variant } \\
\text { TMEM18 rs7561317 }\end{array}$} & \multicolumn{3}{|c|}{ Genotypes (n) } & \multirow{2}{*}{$\begin{array}{c}\text { RAF (\%) } \\
G\end{array}$} & \multirow{2}{*}{$\begin{array}{l}\chi^{2} \\
\mathbf{p}\end{array}$} & \multirow{2}{*}{$\begin{array}{c}\text { OR }(95 \% \text { CI }) \\
p\end{array}$} \\
\hline & $\mathbf{A A}$ & AG & GG & & & \\
\hline Adv36- & 13 & 202 & 541 & 84.9 & 3.17 & $0.79(0.61 ; 1.03)$ \\
\hline $\operatorname{Adv} 36+$ & 7 & 85 & 179 & 81.7 & 0.205 & 0.095 \\
\hline$S H 2 B 1$ rs7498665 & $\mathbf{A A}$ & AG & GG & $\mathbf{G}$ & & \\
\hline Adv36- & 254 & 375 & 127 & 41.6 & 3.74 & $1.11(0.91 ; 1.35)$ \\
\hline $\operatorname{Adv} 36+$ & 91 & 121 & 59 & 44.1 & 0.154 & 0.338 \\
\hline KCTD15 rs29941 & $\mathbf{A A}$ & AG & GG & $\mathbf{G}$ & & \\
\hline Adv36- & 72 & 339 & 345 & 68.1 & 1.17 & $0.94(0.76 ; 1.15)$ \\
\hline $\operatorname{Adv} 36+$ & 32 & 117 & 122 & 66.6 & 0.557 & 0.571 \\
\hline PCSK1 rs6232 & $\mathrm{CC}$ & CT & TT & $\mathbf{C}$ & & \\
\hline Adv36- & 2 & 65 & 689 & 4.6 & $6.59^{\mathrm{a}}$ & $1.67(1.11 ; 2.49)$ \\
\hline $\operatorname{Adv} 36+$ & 1 & 38 & 232 & 7.4 & 0.010 & 0.016 \\
\hline PCSK1 rs6235 & $\mathrm{CC}$ & CG & GG & $\mathbf{G}$ & & \\
\hline Adv36- & 427 & 291 & 38 & 24.3 & 7.56 & $1.34(1.08 ; 1.67)$ \\
\hline $\operatorname{Adv} 36+$ & 131 & 117 & 23 & 30.1 & 0.023 & 0.010 \\
\hline$B D N F$ rs925946 & GG & GT & TT & $\mathbf{T}$ & & \\
\hline Adv36- & 387 & 315 & 54 & 28.0 & 5.79 & $1.16(0.93 ; 1.43)$ \\
\hline $\operatorname{Adv} 36+$ & 135 & 104 & 32 & 31.0 & 0.055 & 0.202 \\
\hline$B D N F$ rs4923461 & $\mathbf{A A}$ & AG & GG & $\mathbf{A}$ & & \\
\hline Adv36- & 484 & 225 & 47 & 78.9 & 6.84 & $1.17(0.91 ; 1.50)$ \\
\hline Adv36+ & 176 & 89 & 6 & 81.4 & 0.033 & 0.247 \\
\hline$S E C 16 B$ rs10913469 & $\mathrm{CC}$ & CT & TT & $\mathbf{C}$ & & \\
\hline Adv36- & 24 & 233 & 499 & 18.6 & 0.21 & $1.05(0.82 ; 1.35)$ \\
\hline Adv36+ & 10 & 85 & 176 & 19.4 & 0.899 & 0.735 \\
\hline$M C 4 R \operatorname{rs} 17782313$ & $\mathrm{CC}$ & CT & TT & $\mathbf{C}$ & & \\
\hline Adv36- & 63 & 295 & 398 & 27.8 & 0.74 & $0.99(0.80 ; 1.23)$ \\
\hline $\operatorname{Adv} 36+$ & 19 & 112 & 140 & 27.7 & 0.690 & 0.985 \\
\hline FTO rs9939609 & $\mathbf{A A}$ & AT & TT & $\mathbf{A}$ & & \\
\hline $\operatorname{Adv} 36-$ & 162 & 385 & 209 & 46.9 & 2.20 & $1.16(0.95 ; 1.41)$ \\
\hline Adv36+ & 68 & 138 & 65 & 50.6 & 0.333 & 0.157 \\
\hline
\end{tabular}

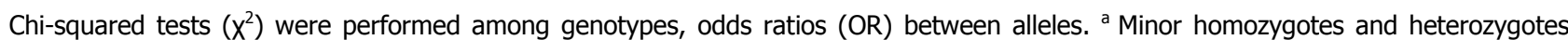
were combined. Adv36-, adenovirus 36 antibody negative; Adv36+, adenovirus 36 antibody positive; CI, confidence interval; RAF, risk allele frequency.

In conclusion, our results suggest that obesity susceptibility loci of PCSK1 and BDNF genes may be related to the status of Adv36 antibodies and consequently to body weight. However, to validate our findings, further investigations in larger cohorts are required.

\section{Conflict of Interest}

Dr. R. Atkinson is the owner and Dr. Z. Lee is Laboratory Director of Obetech, LLC, a company that provides assays for adenoviruses that produce obesity and has several patents for diagnostic assays and vaccines in the area of virus-induced obesity. Dr. Atkinson is a Co-Editor of the International Journal of Obesity. L. Dušátková, H. Zamrazilová, I. Aldhoon Hainerová, B. Sedláčková, J. Včelák, B. Bendlová, M. Kunešová and V. Hainer declare no conflict of interest.

\section{Acknowledgements}

This study was supported by NT/13792-4 Internal Grant Agency of the Ministry of Health of the Czech Republic. 


\section{References}

AHLUWALIA N, DALMASSO P, RASMUSSEN M, LIPSKY L, CURRIE C, HAUG E, KELLY C, DAMSGAARD MT, DUE P, TABAK I, ERCAN O, MAES L, AASVEE K, CAVALLO F: Trends in overweight prevalence among 11-, 13- and 15-year-olds in 25 countries in Europe, Canada and USA from 2002 to 2010. Eur J Public Health 25 (Suppl 2): 28-32, 2015.

AHRENS W, PIGEOT I, POHLABELN H, DE HENAUW S, LISSNER L, MOLNAR D, MORENO LA, TORNARITIS M, VEIDEBAUM T, SIANI A: Prevalence of overweight and obesity in European children below the age of 10. Int J Obes (Lond) 38 (Suppl 2): S99-S107, 2014.

ALDHOON-HAINEROVA I, ZAMRAZILOVA H, ATKINSON RL, DUSATKOVA L, SEDLACKOVA B, HLAVATY P, LEE ZP, KUNESOVA M, HAINER V: Clinical and laboratory characteristics of 1179 Czech adolescents evaluated for antibodies to human adenovirus 36. Int J Obes (Lond) 38: 285-291, 2014.

ALMOND MH, EDWARDS MR, BARCLAY WS, JOHNSTON SL: Obesity and susceptibility to severe outcomes following respiratory viral infection. Thorax 68: 684-686, 2013.

ATKINSON RL, DHURANDHAR NV, ALLISON DB, BOWEN RL, ISRAEL BA, ALBU JB, AUGUSTUS AS: Human adenovirus-36 is associated with increased body weight and paradoxical reduction of serum lipids. Int J Obes (Lond) 29: 281-286, 2005.

BENZINOU M, CREEMERS JW, CHOQUET H, LOBBENS S, DINA C, DURAND E, GUERARDEL A, BOUTIN P, JOURET B, HEUDE B, BALKAU B, TICHET J, MARRE M, POTOCZNA N, HORBER F, LE STUNFF C, CZERNICHOW S, SANDBAEK A, LAURITZEN T, BORCH-JOHNSEN K, ANDERSEN G, KIESS W, KORNER A, KOVACS P, JACOBSON P, CARLSSON LM, WALLEY AJ, JORGENSEN T, HANSEN T, PEDERSEN O, MEYRE D, FROGUEL P: Common nonsynonymous variants in PCSK1 confer risk of obesity. Nat Genet 40: 943-945, 2008.

CHAPMAN SJ, HILL AV: Human genetic susceptibility to infectious disease. Nat Rev Genet 13: 175-188, 2012.

DEN HOED M, EKELUND U, BRAGE S, GRONTVED A, ZHAO JH, SHARP SJ, ONG KK, WAREHAM NJ, LOOS RJ: Genetic susceptibility to obesity and related traits in childhood and adolescence: influence of loci identified by genome-wide association studies. Diabetes 59: 2980-2988, 2010.

DHURANDHAR NV, ISRAEL BA, KOLESAR JM, MAYHEW GF, COOK ME, ATKINSON RL: Increased adiposity in animals due to a human virus. Int J Obes Relat Metab Disord 24: 989-996, 2000.

DUSATKOVA L, ZAMRAZILOVA H, SEDLACKOVA B, VCELAK J, HLAVATY P, ALDHOON HAINEROVA I, KORENKOVA V, BRADNOVA O, BENDLOVA B, KUNESOVA M, HAINER V: Association of obesity susceptibility gene variants with metabolic syndrome and related traits in 1,443 Czech adolescents. Folia Biol 59: 123-133, 2013.

GARCIA MN, PHILPOTT DC, MURRAY KO, ONTIVEROS A, REVELL PA, CHANDRAMOHAN L, MUNOZ FM: Clinical predictors of disease severity during the 2009-2010 A(HIN1) influenza virus pandemic in a paediatric population. Epidemiol Infect: 1-11, 2015.

HINNEY A, VOLCKMAR AL, ANTEL J: Genes and the hypothalamic control of metabolism in humans. Best Pract Res Clin Endocrinol Metab 28: 635-647, 2014.

JANSEN E, AYOUBI TA, MEULEMANS SM, VAN DE VEN WJ: Neuroendocrine-specific expression of the human prohormone convertase 1 gene. Hormonal regulation of transcription through distinct cAMP response elements. J Biol Chem 270: 15391-15397, 1995.

KARLSSON EA, SHERIDAN PA, BECK MA: Diet-induced obesity impairs the T cell memory response to influenza virus infection. J Immunol 184: 3127-3133, 2010.

KOBZOVA J, VIGNEROVA J, BLAHA P, KREJCOVSKY L, RIEDLOVA J: The 6th nationwide anthropological survey of children and adolescents in the Czech Republic in 2001. Cent Eur J Public Health 12: 126-130, 2004.

LOCKE AE, KAHALI B, BERNDT SI, JUSTICE AE, PERS TH, DAY FR, POWELL C, VEDANTAM S, BUCHKOVICH ML, YANG J, CROTEAU-CHONKA DC, ESKO T, FALL T, FERREIRA T, GUSTAFSSON S, KUTALIK Z, LUAN J, MAGI R, RANDALL JC, WINKLER TW, WOOD AR, WORKALEMAHU T, FAUL JD, SMITH JA, HUA ZHAO J, ZHAO W, CHEN J, FEHRMANN R, ET AL.: Genetic studies of body mass index yield new insights for obesity biology. Nature 518: 197-206, 2015. 
MODARRESI F, FAGHIHI MA, LOPEZ-TOLEDANO MA, FATEMI RP, MAGISTRI M, BROTHERS SP, VAN DER BRUG MP, WAHLESTEDT C: Inhibition of natural antisense transcripts in vivo results in gene-specific transcriptional upregulation. Nat Biotechnol 30: 453-459, 2012.

NEAD KT, LI A, WEHNER MR, NEUPANE B, GUSTAFSSON S, BUTTERWORTH A, ENGERT JC, DAVIS AD, HEGELE RA, MILLER R, DEN HOED M, KHAW KT, KILPELAINEN TO, WAREHAM N, EDWARDS TL, HALLMANS G, VARGA TV, KARDIA SL, SMITH JA, ZHAO W, FAUL JD, WEIR D, MI J, XI B, QUINTEROS SC, COOPER C, SAYER AA, JAMESON K, GRONTVED A, FORNAGE M, ET AL.: Contribution of common non-synonymous variants in PCSK1 to body mass index variation and risk of obesity: a systematic review and meta-analysis with evidence from up to 331175 individuals. Hum Mol Genet 24: 3582-3594, 2015.

NICHOLSON JR, PETER JC, LECOURT AC, BARDE YA, HOFBAUER KG: Melanocortin-4 receptor activation stimulates hypothalamic brain-derived neurotrophic factor release to regulate food intake, body temperature and cardiovascular function. J Neuroendocrinol 19: 974-982, 2007.

PASARICA M, SHIN AC, YU M, OU YANG HM, RATHOD M, JEN KL, MOHANKUMAR S, MOHANKUMAR PS, MARKWARD N, DHURANDHAR NV: Human adenovirus 36 induces adiposity, increases insulin sensitivity, and alters hypothalamic monoamines in rats. Obesity (Silver Spring) 14: 1905-1913, 2006.

PASARICA M, MASHTALIR N, MCALLISTER EJ, KILROY GE, KOSKA J, PERMANA P, DE COURTEN B, YU M, RAVUSSIN E, GIMBLE JM, DHURANDHAR NV: Adipogenic human adenovirus Ad-36 induces commitment, differentiation, and lipid accumulation in human adipose-derived stem cells. Stem Cells 26: 969-978, 2008.

SHANG Q, WANG H, SONG Y, WEI L, LAVEBRATT C, ZHANG F, GU H: Serological data analyses show that adenovirus 36 infection is associated with obesity: a meta-analysis involving 5739 subjects. Obesity (Silver Spring) 22: 895-900, 2014.

TANAKA S, INOUE S, ISODA F, WASEDA M, ISHIHARA M, YAMAKAWA T, SUGIYAMA A, TAKAMURA Y, OKUDA K: Impaired immunity in obesity: suppressed but reversible lymphocyte responsiveness. Int J Obes Relat Metab Disord 17: 631-636, 1993.

VANGIPURAM SD, YU M, TIAN J, STANHOPE KL, PASARICA M, HAVEL PJ, HEYDARI AR, DHURANDHAR $\mathrm{NV}$ : Adipogenic human adenovirus-36 reduces leptin expression and secretion and increases glucose uptake by fat cells. Int J Obes (Lond) 31: 87-96, 2007. 